\title{
Higher Education as Self-Transformation ${ }^{*}$
}

\author{
Tania Stoltz \\ Federal University of Paraná, DTFE, \\ Paraná, Brazil
}

\author{
Ulrich Weger \\ Witten-Herdecke University, \\ Witten, Germany
}

\author{
Marcelo da Veiga \\ Alanus University of Arts and \\ Social Sciences, Alfter, Germany
}

Contemporary higher education has been largely defined by the economy and by its capacity to generate employment and income. At no other time has there been such an overwhelming need to review the objectives of higher education. Growing social inequality, despite the progress of science and technology, together with progressive environmental degradation, demand a review of the objective of education aimed merely at gaining knowledge and techniques for adaptation to the world of work. This study aims to discuss higher education as a contribution to self-transformation towards a greater commitment to others. This relationship will be approached based on the discipline of Educational Psychology, which is offered for bachelors' degrees and is concerned with theories regarding human development and learning.

Keywords: higher education, educational psychology, self-transformation

\section{Introduction}

This study aims to discuss higher education as a contribution to self-transformation towards a greater commitment to others. The discussion is based on the discipline of Psychology of Education within the Pedagogy Graduation course and is supported theoretically by the works of Rudolf Steiner, Schiller and Goethe. Self-transformation, from the perspective of Rudolf Steiner, implies a movement involving both knowledge and action and which is expressed both internally and externally (Steiner, 2005). Resistance to a set of current day characteristics justifies the focus on self-transformation: individualism, hedonism, consumerism, and competitiveness. To a great extent the symptoms of this time can be seen to be: indifference in relation to others and to nature, lack of feeling of existence, disquiet, anxiety, depression, dissatisfaction, fear, lack of control and lack of solidarity. As such, this article proposes to address the recovery of "Erfahrung" (experience) in knowledge, this being a principal aspect of Goethe's cognitive method. "Erfahrung" involves firstly the undifferentiated observation of reality, followed by the integration of sensitivity and reason.

Among the post-modernist movement in our century there is criticism regarding the predominance of reason and the belief in the impossibility of having access to the knowledge of others, as the latter would be beyond our concepts. On the other hand, an appreciation of feelings and difference can be seen, as well as the rediscovery of creativity. Everything is possible and can be valid. Current society is dominated by multiplicity and by the

\footnotetext{
${ }^{*}$ This work was supported by CNPq, Brazil (grant number 311402/2015-1).

Tania Stoltz, Ph.D., Professor of Educational Psychology, Department of Education, Federal University of Paraná.

Ulrich Weger, Ph.D., Professor of Fundamentals of Psychology, Department of Psychology and Psychotherapy, Witten-Herdecke University.

Marcelo da Veiga, Ph.D., Professor for Philosophy and Social Innovation, Head of Institute for Philosophy and Aesthetics, Alanus University of Arts and Social Sciences.
} 
relativity of things and ideas. Despite recovering the subject's links with the world, the post-modernist movement tends to revert to the other extreme. Also as a result of modernist restraint, there is now an unbridled search for pleasure, the exacerbation of feelings and sensations, individualism, superficiality and an emphasis on practical activity, often at the expense of theoretical knowledge. There is a certain discomfort in the air, as there also was at the time when reason was defended. Education urgently needs to review its process.

\section{The Need to Review Higher Education}

In a thought-provoking article, Bauman (2003) describes the challenges faced by education today. Referring to liquid modernity, where external certainties are diluted in a sea of possibilities, Bauman emphasizes the lack of control and the fear experienced by current society. Education's greatest challenge would lie precisely in regarding it while taking liquid modernity into consideration, as well as taking into account that liquid modernity confronts the very idea of education. The excess of information to which we have rapid access today leads to the collapse of ready and long-lasting external models. Knowing how to be and how to live become the differentiating elements between people, as much as or more than having information. Education has faced countless challenges at different historic moments in time and has always been able to transform itself. The challenge faced today is unequalled. The very meaning of educating in institutions is being put at stake, given that all education points towards transitoriness (Bauman, 2003). Higher education, when facing this state of things, is called on to completely review the way it works. Being yourself and not the same as others is a requirement of current times. New ways to bring subjects closer to their innerness need to be thought of, connecting this to the world in higher education.

In the face of modern liquidity, higher education could have its meaning renewed by promoting personal development and social change (Nelson, 2016; Robinson \& Blenker, 2014). Mention is made of "transformational learning" which contributes to significant personal changes which enable broader organizational or social change (Tennant, 2012). This objective requires educators who are culturally responsive (Jenkins, 2016) and integrate feelings and thought within the perspectives of transformation (Beard, Humberstone, \& Clayton, 2014). The change required encompasses the transition from authority to autonomy which manifests itself as centred on the student, life-long learning, individualization, experiencing democracy in the classroom, effective student participation and self-government (Lum, 2014). It can be said that change in higher education is much more directed towards how to move forward rather than indicating a single way forward (Bauman, 2003). Evaluation itself should be more aimed at the development of inner criteria instead of being limited to external criteria, which alienate students from their authentic self and lead to problems in human relations and in the relations between mankind and nature (Lin, 2013).

Growing interest among researchers in the proposal of a renewed higher education can be seen. Zhang (2013), for instance, proposes the development of an ethical individuality at university expressed through theoretical and practical projects in response to the demands of the community. In this sense, the development of spirituality is one of the recurring themes. Higher education, understood in this way, would not just be a means of producing knowledge and transferring it, but rather a means of developing greater wisdom (Meixner, 2013). The focus would be more on the process and not on the product, directed towards the inner and outer movement of students themselves, of the people around them, of nature, of the universe. The change needed in higher education can be expressed in the development of cultural awareness, spirituality and self-empowerment (Lin, Oxford, \& Brantmeier, 2013). 
Learning that transforms is potentialized in activities that turn the attention towards inner processes, such as meditation, processes directed towards the body, psychological or spiritual practices. In the midst of the bombardment of information and external stimuli, lack of security and external control, the importance of practices aimed at increasing inner awareness, discernment and self-regulation stands out. The transformation required also relates to the possibility of transcending from ordinary states of attention (Kies, 2014; Cox, 2010; McGill \& Kippers, 2012; Fleming, 2012).

In the face of this scenario, it can be said that flexibility, creativity, emotion, reason, innerness, knowledge expressed in actions, cultural responsiveness and ethical individuality are characteristics to be developed in higher education in times of liquid modernity. Outside uncertainties bring individuals face-to-face with themselves. Thought needs to be given to reconnecting them to their individuality and to the world in continual change guided by awareness of the present and pointing to the future. In this case, attention is directed more towards the process than the product because the product is transitory, but the ability to reinvent oneself, to abandon old habits and develop a sense of autonomy and interdependence remains as a possible way of addressing the unpredictability that is proper to liquid modernity. Standing out among the practices aimed at developing these characteristics is the integration of work between science and art in higher education.

\section{Steiner: The Balance between Art and Science in the Cognitive Process}

Steiner's proposal for education is mainly based on Goethe and Schiller, who respond to his critique of late 19th century positivism (Welburn, 2005). For Goethe, everything around us has an evolutionary cycle. Nature has a previous evolution, which man did not take part in and which leads to man, who then becomes part of the continuity of evolution. The method proposed by Goethe (1981) points to the need to see things from various different angles. Each aspect reveals and hides, depending on the angle from which someone is looking at something. There are more or less complete perspectives. In art we find the synthesis of many aspects.

For Goethe (1981), art is the dimension where man rises from creature to creator, but does not distance himself from nature. Goethe does not separate art and science to reach the creative essence of things and become the creator (Steiner, 1979). This demands supreme knowledge. Schiller (1990), a contemporary of Goethe, concerned himself with art and education. He understands man as being dominated by two impulses: the impulse of form and the impulse of matter (or material impulse). Real man is marked by the energy derived from the material impulse. The ideal man puts order and reason in things. The former impulse characterizes passion and diversity, whilst the latter characterizes reason and need for rules. These two trends subjugate man in many ways, as in the savagery of society dominated by passions, and as in barbarity, represented by society driven by the imposition of principles and rules destitute of passion. These two impulses are overcome by the ludic impulse, which can only be achieved through creative activity and represents the balance between passion and reason. According to Schiller, aesthetic education prepares the way for an ethical freedom established by a process. But the exercising of freedom requires the development of skills and abilities. The value of art lies in affording man's cultural evolution (Steiner, 1994).

The development of humanity depends on the relationship between these two impulses: the sensitive impulse (driving the passions) and the formal impulse (guiding reason). What is desired is an evolution of consciousness, in the moral sense, and of spontaneity, understanding it as the self-active being arising from reason. Each person has to achieve humanity (Veiga, 2012; 2014; 2015). For Steiner, our very existence is a craft or an art, which contains both a cultural heritage and a being in evolution. Man needs to cultivate himself in order 
to develop his freedom. Education has the function of creating prerequisites for freedom by enabling access to culture. Steiner (1996) proposes an integral education, focused on the body, feelings and mind; an education aimed at autonomy and the development of citizenship. Steiner's proposal of is one of education as art, which arises from the confrontation with the people one deals with. Art, as a synthesis of many aspects, leads to the importance of signification, beyond liking or not liking. Thinking leads to the experience of the ideal nexus, to that which composes things. "Our spirit makes the combination of the blocks of thought only in accordance with their content. Therefore, when thinking we apply the principle of experience in its most rudimentary form" (Steiner, 2004, pp. 49-50). Further on, Steiner (2004, p. 53) states: "We should imagine two things: first, that it is through activity that we lead the world of ideas to manifest itself and, simultaneously, that what we actively call to existence reports to its own laws". There is a fundamental difference here between Steiner and Kant, Schopenhauer and Fichte when they state that the laws that we admit to explain the world are merely a product of our own imagination, the result of what we introduce into the world as a product of our imagination.

Free will underscores the meaning of reason and wisdom in human attitudes (Steiner, 2005). Man's freedom indicates that he is always capable of making mistakes when choosing between one direction and another, and that is where evil arises. The development of morality does not represent reaching an abstract rule. The expansion of our consciousness is what gives knowledge its moral repercussion and, therefore, morality depends on our involvement and on knowledge in specific circumstances. This situation reveals an evolution in the consciousness both of humanity and also of each individual.

The universal aspect of thought is the concept, which shapes the multitude. Thought lies between experience and concept, and the field of thought is human consciousness (Steiner, 2004, p. 51). Thought must express a sensitive reason or a rational sensitivity. Therefore, Steiner's education involves knowledge and commitment to action. It is an education that corresponds to the requirements of the nature of the human being and points to universalism and ethical individualism. Thus, it represents a cultural evolution that is added to the biological evolution. "It can be said that every single man carries inside himself, with regard to disposition and destination, an ideal and pure man, and the great task of his existence is to agree, in all of his modifications, with his unchangeable unity" (Schiller, 1990, p. 32).

For Steiner (2004), we actively perceive a phenomenon and also produce it at the same time. The learning process, on the one hand, should bring man closer to the sensory world and, on the other, closer to the ideal essence of this world. Man should combine, as an activity of his own, these two factors of reality.

\section{Method}

This is a qualitative and exploratory study aimed at examining self-transformation based on the relation between knowledge and self-knowledge in the discipline of Psychology of Education at bachelor degree level. The participants of the study were eleven students from the discipline of Psychology of Education, which is part of the third year subject matters of the Pedagogy Course at the Federal University of Paraná, Brazil. In the second semester the contents of the discipline taught Vygotsky's social interaction approach and followed the following steps: (1) Presentation and transcription of short films made by the students on the topics to be addressed (e.g., babies, children, adolescence, etc.); (2) Studying works of Vygotsky relating to the contents filmed; (3) Understanding the reality filmed based on Vygotsky; (4) Searching for contemporary literature involving the topic studied and Vygotsky; (5) Searching for works of art representative of Vygotsky's ideas; and (6) Creative productions made by the students addressing what was significant in the contents discussed. At 
the end of the semester, the students were invited to assess the methodology used and indicate its possible contribution to knowledge of Vygotsky's theory and to their self-knowledge. The analysis in this article aims to identify recurring themes in what the participants said at the end of the discipline in relation to the question: "Considering the methodology used in the discussion of Psychology of Education theorists, which brings together science and art, discuss the process of human knowledge and self-knowledge". The themes resulted from a series of floating readings (leituras flutuantes) of the material collected and identification of all the significant aspects cited (pre-indicators). Bringing the pre-indicators together enabled the indicators themselves to be reached and the agglutinated indicators lead to the establishment of cores of signification, containing senses and meanings (Aguiar \& Ozella, 2006).

\section{Results and Discussion}

The results indicated three cores of signification: (1) Filming of reality triggering motivation for the contents and their pertinence; (2) The choice of the works of art requiring the understanding of significant aspects of Vygotsky's theory; and (3) The link between reality, knowledge and self-knowledge through work integrating science and art.

\section{Filming of Reality Triggering Motivation for the Contents and Their Pertinence}

The fact of starting with reality brought to light the importance of total observation, without judgement and without classification, prior to working with scientific knowledge. On the other hand, the group of students chose what they were going to film and this required their having links with the realities filmed. This was essential for motivation and interest in knowing reality in a broad manner, as well as for the possibility of the Vygotskian explanation. Experiencing reality recorded through films, prior to discussing theory, showed itself to be very important for understanding the cultural context. The films showed current day children, adolescents and adults interacting with different cultural objects. Examples are used below to illustrate the contribution made by the films.

I noticed a change in my way of thinking my educational practice in relation to the contents of Psychology, with effect from the beginning of this year, a sort of personal and academic growth that today interferes in my praxis... (Joana)

Both knowledge and self-knowledge when allied to something meaningful to the student facilitate learning. As such, the use of art with regard to Psychology of Education is interesting, since it enables the student to make connections with reality around him. (Luana)

\section{The Role of Art and the Role of Producing Creative Activities}

The participants highlighted the choice of the works of art requiring the understanding of significant aspects of Vygotsky's theory. Understanding of key aspects of the theory was necessary both in order to choose a representative work of art and also to achieve a creative and artistic production. On the other hand, when a person becomes involved in a creative process aimed at that which is significant in Vygotsky's work, they become entirely involved, both sensitively and rationally, thus also enabling greater understanding of the theory. Here are some examples.

I believe that the teacher's methodology has contributed greatly to my knowledge. Reflecting on what I read and incorporating it into a work of art requires me to make a greater effort, as the work of art has to make sense with the book. I believe that this contributes to building my knowledge. (Íria)

Lessons become more interesting when we talk about theory through our artistic expressions. It's interesting to see how knowledge/theory can be different for each person. (Aline) 
Producing an artistic activity after reading and discussion helps to memorize knowledge, almost like producing a synthesis after the thesis and antithesis. (Joana)

When a person does an artistic activity individually they present what they have abstracted, and this helps us to know what they have really learnt and whether something is still lacking. (Amélia)

\section{The Link between Reality, Knowledge and Self-Knowledge through Work Integrating Science and Art}

During lessons the students' work was aimed first of all at general reflection on reality and, later on, what they had observed was considered based on the social interactionist theory. Following this, important ideas of Vygotsky were represented through works of art chosen by the participants. In addition the participants made creative productions on what was significant for working at school. These productions were especially valued because they also involved emotions and feelings.

When we choose someone else's work of art, we have to observe human knowledge that has already been produced. When we make our own work of art, we have the opportunity to think about what we live, our experiences, knowledge and feelings that we want to expose, that is to say, we develop our self-knowledge. (Jenifer)

I think that this methodology that brought together art and science was much more productive, it helped to incorporate more the contents of the text (book), it was very enriching with regard to knowledge, as well as making the lessons more dynamic. (Julia)

It's very interest to study art together with theory, as it is through art that we can truly express ourselves, how we see in ourselves the theory we are studying. We can also perceive the knowledge that we really do absorb through art, and generally these are the points that most affect us. This process is very rich, since we gain more knowledge through it, we see things in ourselves that we didn't recognize before and when we work on ourselves first it's much easier to take this knowledge with us. (Aline)

As can be seen, knowledge of the theory was facilitated by experiencing reality in the classroom, using works of art as mediators, and above all through the creative and artistic productions which were especially mentioned, thus broadening understanding through experience. On the other hand, the process of self-knowledge occurred in parallel within "Erfahrung", in the interaction between sensitivity and reason, enabled by the creative-artistic activities and the scientific-creative activities.

\section{Conclusion}

This study proposes a differentiated way of working in higher education, beginning with reality, articulating sensitivity and reason in understanding it, and aims to achieve the development of transforming actions in the person's own reality and in the reality surrounding them. It is therefore aimed at the person as a whole, their willing, feeling and thinking towards developing better and more sensitive people. The greatest current day challenge in education lies not in repeating that which is dead, scientific knowledge that has already been built, but rather in using that knowledge to be able to invest in the future, towards possibilities of being and living in a more human manner. Of relevance here is the important question posed by Steiner in his book Truth and Knowledge (1980): "What use is all this knowledge? If we don't become better through knowledge, what use are all current day erudition, technique and science?"

In opposition to education as a promoter of savagery or barbarity, education that combines feeling and thinking in meaningful creative activity, as well as reflection on this process, leads to the individual's unexpected encounter with himself and, at the same time, with humanity (Schleder \& Stoltz, 2014; Stoltz \& Weger, 2012; 2015). Creative activity, triggering experienced thinking and self-transformation, modifies the subject who, in turn, feels ethically committed to humanity, adopting a system of values that is not external to 
him, but rather the result of his involvement with reality.

Knowing oneself better is necessary in order to be able to perceive and experience the needs of others. Integrating art into university teaching is fundamental for promoting teaching and learning of a more human nature and thus contributing to a society that is less indifferent, more caring and human (Stoltz \& Weger, 2012; 2015; Veiga \& Stoltz, 2014).

More than just merely presenting different theoretical possibilities and the evolution of research, Psychology of Education should begin with observing real children and adolescents, and also with the students' own biographies, in order to get closer to current day man in transformation. The explanatory possibilities of different theories could be presented afterwards, taking into consideration the extent to which they are still applicable to contemporary reality. This way of working integrates knowledge and self-knowledge by not distancing itself from "Erfahrung" (experience) and seeks to develop an up to date viewpoint of Psychology of Education. At the same time, this perspective broadens the possibilities of the theoretical approaches themselves.

\section{References}

Aguiar, W. M. J., \& Ozella, S. (2006). Núcleos de significação como instrumento para a apreensão da constituição dos sentidos. Psicologia, Ciência e Profissão. [online], 26(2), 222-245. Retrieved April 29, 2007, from http://pepsic.bvsalud.org/pdf/pcp/v26n2/v26n2a06.pdf

Bauman, Z. (2003). Educational challenges of the liquid-modern era. Diogenes, 50(1), 15-26. Retrieved October 27, 2016, from dio.sagepub.com

Beard, C., Humberstone, B., \& Clayton, B. (2014). Positive emotions: Passionate scholarship and student transformation. Teaching in Higher Education, 19(6), 630-643.

Cox, R. D. (2010). Evolution of the soul: The transformative connection between cultural consciousness, spirituality, and self-empowerment for African American community college adult learners (Doctoral dissertation). Retrieved from Dissertation Abstracts International Section A: Humanities and Social Sciences. U North Carolina at Greensboro, US. US: ProQuest Information \& Learning.

Fleming, T. (2012). The self in transformation: What gets transformed in transformative learning? In C. J. B. McGill, \& S. M. Kippers (Eds.), Pathways to transformation: Learning in relationship (pp. 343-353). Charlotte, NC, US: IAP Information Age Publishing.

Goethe, J. W. (1981) Goethe anschauendes Denken. Frankfurt am Main: Insel Verlag.

Jenkins, C. M. (2016). It's the right thing to do: The voices of seven white culturally responsive professors of education (Doctoral dissertation). Retrieved from Dissertation Abstracts International Section A: Humanities and Social Sciences. Texas A\&M University, Educational Administration and Human Resource Development. US: ProQuest Information \& Learning.

Kies, K. M. (2014). Transforming perspectives with expanded inner knowing: How attention to the varieties of lived experience leads to transformative learning (Doctoral dissertation). Retrieved from Dissertation Abstracts International: Section B: The Sciences and Engineering. Saybrook Graduate School and Research Center, US. US: ProQuest Information \& Learning.

Lin, J. (2013). Education for transformation and an expanded self: Paradigm shift for wisdom education. In J. Lin, R. L. Oxford, E. J. Brantmeier (Eds.), Re-envisioning higher education: Embodied pathways to wisdom and social transformation (Transforming education for the future) (pp. 23-32). Charlotte, NC, US: IAP.

Lin, J., Oxford, R. L., \& Brantmeier, E. J. (Eds.) (2013). Re-envisioning higher education: Embodied pathways to wisdom and social transformation (Transforming education for the future). Charlotte, NC, US: IAP.

Lum, G. (2014). Responding to the problems of higher education: A case of liquidity or liquidation? British Journal of Sociology of Education, 35(4), 626-632.

McGill, C. J. B., \& Kippers, S. M. (2012). Pathways to transformation: Learning in relationship. Charlotte, NC, US: IAP Information Age Publishing. 
Meixner, C. (2013). Locating self by serving others: A journey to inner wisdom. In J. Lin, R. L. Oxford, E. J. Brantmeier (Eds.), Re-envisioning higher education: Embodied pathways to wisdom and social transformation (Transforming education for the future) (pp. 317-334). Charlotte, NC, US: IAP.

Nelson, A. (2016). Exploring the transformation of actorship among students at a small Swedish university: Background, actorship and achievement. Higher Education, 71(2), 289-305.

Robinson, S., \& Blenker, P. (2014). Tensions between rhetoric and practice in entrepreneurship education: An ethnography from Danish education. EuropeanJournalof Higher Education, 4(1), 80-93.

Schiller, F. (1990). A educação estética do homem: numa série de cartas. Trad. Roberto Schwarz e Márcio Suzuki. São Paulo: Iluminuras.

Schleder, K., \& Stoltz, T. (2014). Art just for Artist? Considerations based on R. Steiner. RoSE-Research on Steiner education, 5 , 112-120. Retrieved October 11, 2016, from http://www.rosejourn.com/index.php/rose/article/view/212/221

Steiner, R. (1996). A educação da criança: segundo a ciência espiritual (3rd ed.). São Paulo:Antroposófica.

Steiner, R. (1994). Arte e Estética segundo Goethe: Goethe como inaugurador de uma estética nova. Tradução de Marcelo da Veiga. São Paulo: Antroposófica.

Steiner, R. (2005). Die philosophie der freiheit: GrundlageeinermodernenWeltanschauung. Dornach: Rudolf Steiner Verlag.

Steiner, R. (1979). Grundlinieneiner Erkenntnistheorie der Goetheschen Weltanschauung: mitbesondererRücksicht auf Schiller. Dornach: Rudolf Steiner Verlag.

Steiner, R. (2004). O método cognitivo de Goethe: Linhas básicas para uma gnosiologia da cosmovisãogoethiana (2nd ed.). São Paulo: Antroposófica.

Steiner, R. (1980). Wahrheit und Wissenschaft: Vorspieleiner "Philosophie der Freiheit". Dornach: Rudolf Steiner Verlag.

Stoltz, T., \& Weger, U. (2012). Piaget and Steiner: Science and art in the process of formation. Research on Steiner Education (RoSE), 3(1), 134-145. Retrieved October 25, 2012, from http://www.rosejourn.com/index.php/rose/article/viewFile/106/ 131

Stoltz, T., \& Weger, U. (2015). O pensar vivenciado na formação de professores. Educar em Revista, 56, 67-83. Retrieved November 10, 2016, from http://dx.doi.org/10.5380/educar.v0i56.41444

Tennant, M. (2012). The learning self: Understanding the potential for transformation (1st ed.). San Francisco: Jossey-Bass.

Veiga, M. da (2012). How much "spirit" should higher education afford? Other Education: The Journal of Educational Alternatives, 1, 166-170.

Veiga, M. da (2014). O significado do pensamento filosófico para a Pedagogia Waldorf. In T. Stoltz, \& M. da Veiga (Orgs.) $O$ pensamento de Rudolf Steiner no debate cientifico (pp. 09-32). Campinas, SP: Editora Alínea.

Veiga, M. da (2015). Revisiting humanism as guiding principle for education: An excursion in to Waldorf Pedagogy. Educar em Revista, 56, 19-31. Retrieved November 10, 2016, from http://dx.doi.org/10.5380/educar.v0i56.41417

Veiga, M. da, \& Stoltz, T. (Orgs.) (2014). O pensamento de Rudolf Steiner no debate científico. Campinas, SP: Editora Alínea.

Welburn, A. (2005). A filosofia de Rudolf Steiner e a crise do pensamento contemporâneo. São Paulo: Madras.

Zhang, A. (2013). Service learning as civic and spiritual engagement. In J. Lin, R. L. Oxford, \& E. J. Brantmeier (Eds.), Re-envisioning higher education: Embodied pathways to wisdom and social transformation (Transforming education for the future) (pp. 285-297). Charlotte, NC, US: IAP. 